\title{
Necessity of COVID-19 vaccination in previously infected individuals
}

Nabin K. Shrestha, ${ }^{1}$ Patrick C. Burke, ${ }^{2}$ Amy S. Nowacki, ${ }^{3}$ Paul Terpeluk, ${ }^{4}$ Steven M. Gordon ${ }^{1}$

From the Departments of ${ }^{1}$ Infectious Diseases, ${ }^{2}$ Infection Prevention, ${ }^{3}$ Quantitative Health Sciences, and ${ }^{4}$ Occupational Health, Cleveland Clinic, Cleveland, Ohio.

Keywords: SARS-CoV-2; COVID-19; Incidence; Vaccines; Immunity;

Running Title: COVID-19 vaccination if already infected

\section{Corresponding author:}

Nabin K. Shrestha, MD, MPH

9500 Euclid Avenue / G-21

Cleveland, $\mathrm{OH} 44195$

Phone: 216-636-1873 / Fax: 216-445-9446 / Email: shrestn@ccf.org

Summary: Cumulative incidence of COVID-19 was examined among 52238 employees in an American healthcare system. COVID-19 did not occur in anyone over the five months of the study among 2579 individuals previously infected with COVID-19, including 1359 who did not take the vaccine. 
medRxiv preprint doi: https://doi.org/10.1101/2021.06.01.21258176; this version posted June 19, 2021. The copyright holder for this preprint (which was not certified by peer review) is the author/funder, who has granted medRxiv a license to display the preprint in perpetuity.

It is made available under a CC-BY-NC-ND 4.0 International license .

\section{ABSTRACT}

Background. The purpose of this study was to evaluate the necessity of COVID-19 vaccination in persons previously infected with SARS-CoV-2.

Methods. Employees of the Cleveland Clinic Health System working in Ohio on Dec 16, 2020, the day COVID-19 vaccination was started, were included. Any subject who tested positive for SARS-CoV-2 at least 42 days earlier was considered previously infected. One was considered vaccinated 14 days after receipt of the second dose of a SARS-CoV-2 mRNA vaccine. The cumulative incidence of SARS-CoV-2 infection over the next five months, among previously infected subjects who received the vaccine, was compared with those of previously infected subjects who remained unvaccinated, previously uninfected subjects who received the vaccine, and previously uninfected subjects who remained unvaccinated. Results. Among the 52238 included employees, 1359 (53\%) of 2579 previously infected subjects remained unvaccinated, compared with 20804 (42\%) of 49659 not previously infected. The cumulative incidence of SARS-CoV-2 infection remained almost zero among previously infected unvaccinated subjects, previously infected subjects who were vaccinated, and previously uninfected subjects who were vaccinated, compared with a steady increase in cumulative incidence among previously uninfected subjects who remained unvaccinated. Not one of the 1359 previously infected subjects who remained unvaccinated had a SARS-CoV-2 infection over the duration of the study. In a Cox proportional hazards regression model, after adjusting for the phase of the epidemic, vaccination was associated with a significantly lower risk of SARS-CoV-2 infection among those not previously infected (HR 0.031, 95\% CI 0.015 to 0.061 ) but not among those previously infected (HR $0.313,95 \%$ CI 0 to Infinity).

Conclusions. Individuals who have had SARS-CoV-2 infection are unlikely to benefit from COVID-19 vaccination, and vaccines can be safely prioritized to those who have not been infected before. 
medRxiv preprint doi: https://doi.org/10.1101/2021.06.01.21258176; this version posted June 19, 2021. The copyright holder for this preprint (which was not certified by peer review) is the author/funder, who has granted medRxiv a license to display the preprint in perpetuity.

It is made available under a CC-BY-NC-ND 4.0 International license .

\section{INTRODUCTION}

The two FDA-approved (BNT162b2 mRNA [Pfizer-BioNTech] and mRNA-1273 [Moderna]) mRNA vaccines have been shown to be very efficacious in protecting against Severe Acute Respiratory Syndrome (SARS) - associated Coronavirus-2 (SARS-CoV-2) infection [1,2]. The effectiveness of the Pfizer-BioNTech vaccine in a real-world setting has also been shown to be comparable to the efficacy demonstrated in clinical trials $[3,4]$. Given these, there has been an understandable desire to vaccinate as many people as possible.

The ability to vaccinate a large part of the population is limited by the supply of vaccine. As of March 21, 2021, $78 \%$ of 447 million doses of the coronavirus disease 2019 (COVID-19) vaccines that had been deployed had gone to only ten countries [5]. The COVAX initiative was borne out of the recognition that equitable distribution of vaccines worldwide was essential for effective control of the COVID-19 pandemic. However, the reality is that there is great disparity in the availability of vaccines across countries. Countries with limited supplies of vaccine have to prioritize how their supply of vaccines will be allocated within their populations. Criteria used for such prioritization have included profession, age, and comorbid conditions. Data that inform prioritization criteria with help maximize the benefits of whatever vaccine is available.

Observational studies have found very low rates of reinfection among individuals with prior SARS-CoV-2 infection [6-8]. This brings up the question about whether it is necessary to vaccinate previously infected individuals. These studies notwithstanding, there remains a theoretical possibility that the vaccine may still provide some benefit in previously infected persons. A prior large observational study concluded that immunity from natural infection cannot be relied on to provide adequate protection and advocated for vaccination of previously infected individuals [9]. The CDC website recommends that persons previously infected with SARS-CoV-2 still get the vaccine [10]. Despite these recommendations, credible reports of previously infected persons getting COVID-19 are rare. The rationale often provided for getting the COVID-19 vaccine is that it is safer to get vaccinated than to get the disease. This is 
medRxiv preprint doi: https://doi.org/10.1101/2021.06.01.21258176; this version posted June 19, 2021. The copyright holder for this preprint (which was not certified by peer review) is the author/funder, who has granted medRxiv a license to display the preprint in perpetuity.

It is made available under a CC-BY-NC-ND 4.0 International license .

certainly true, but it is not an explanation for why people who have already had the disease need to be vaccinated. A strong case for vaccinating previously infected persons can be made if it can be shown that previously infected persons who are vaccinated have a lower incidence of COVID-19 than previously infected persons who did not receive the vaccine.

The purpose of this study was to attempt to do just that, and thereby evaluate the necessity of the COVID-19 vaccine in persons who were previously infected with SARS-CoV-2. 


\section{METHODS}

\section{Study design}

This was a retrospective cohort study conducted at the Cleveland Clinic Health System in Ohio, USA. The study was approved by the Cleveland Clinic Institutional Review Board. A waiver of informed consent and waiver of HIPAA authorization were approved to allow access to personal health information by the research team, with the understanding that sharing or releasing identifiable data to anyone other than the study team was not permitted without additional IRB approval.

\section{Setting}

PCR testing for SARS-CoV-2 at Cleveland Clinic began on March 12, 2020, and a streamlined process dedicated to the testing of health care personnel (HCP) was begun shortly thereafter. All employees with a positive SARS-CoV-2 test were interviewed by Occupational Health, with date of onset of symptoms of COVID-19 being one of the questions asked. Vaccination for COVID-19 began at Cleveland Clinic on December 16, 2020. When initially started it was the Pfizer-BioNTech vaccine that was administered, until the Moderna vaccine became available, from which time employees received one or the other. All employees were scheduled to receive their second vaccine dose 28 days after the first one, regardless of which vaccine was given. The employee cohort was chosen for this study because of documentation of their COVID-19 vaccination and of any SARS-CoV-2 infection in the Occupational Health database.

\section{Participants}

All employees of the Cleveland Clinic Health System, working in Ohio, on Dec 16, 2020, were screened for inclusion in the study. Those who were in employment on December 16, 2020, were included. 
medRxiv preprint doi: https://doi.org/10.1101/2021.06.01.21258176; this version posted June 19, 2021. The copyright holder for this preprint (which was not certified by peer review) is the author/funder, who has granted medRxiv a license to display the preprint in perpetuity.

It is made available under a CC-BY-NC-ND 4.0 International license .

\section{Variables}

SARS-CoV-2 infection was defined as a positive nucleic acid amplification test. The date of infection was taken to be the date of onset of symptoms when available, and the date of specimen collection when not. A person was considered vaccinated 14 days after receipt of the second dose of the vaccine (which would have been 42 days after receipt of the first dose of the vaccine for most subjects). For the sake of consistency in the duration assumed for development of natural and vaccine immunity, any person who tested positive for SARS-CoV-2 at least 42 days before the vaccine rollout date, was considered previously infected. Other covariates collected were age, job location, job type (patient-facing or non-patient facing), and job category. The job location variable could be one of the following: Cleveland Clinic Main Campus, regional hospital (within Ohio), ambulatory center, administrative center, or remote location. The job category was one of the following: professional staff, residents/fellows, advance practice practitioners, nursing, pharmacy, clinical support, research, administration, and administration support.

\section{Outcome}

The study outcome was time to SARS-CoV-2 infection, the latter defined as a positive nucleic acid amplification test for SARS-CoV-2 on or after December 16, 2020. Time to SARS-CoV-2 infection was calculated as number of days from December 16, 2020 (vaccine rollout date) to SARS-CoV-2 infection. For those with a prior SARS-CoV-2 infection positive tests within 90 days of the first positive test were considered part of the initial episode of illness. Employees that had not developed a SARSCoV-2 infection were censored at the end of the study follow-up period (May 15, 2021). Those who received the Johnson \& Johnson vaccine (81 subjects) without having had a SARS-CoV-2 infection were censored on the day of receipt of the vaccine, and those whose employment was terminated during the study period before they had SARS-CoV-2 infection (2245 subjects) were censored on the date of 
medRxiv preprint doi: https://doi.org/10.1101/2021.06.01.21258176; this version posted June 19, 2021. The copyright holder for this preprint (which was not certified by peer review) is the author/funder, who has granted medRxiv a license to display the preprint in perpetuity.

It is made available under a CC-BY-NC-ND 4.0 International license .

termination of employment. The health system never had a requirement for asymptomatic employee test screening. Most of the positive tests, therefore, would have been tests done to evaluate suspicious symptoms. A small proportion would have been tests done as part of pre-operative or pre-procedural screening.

\section{Statistical analysis}

A Simon-Makuch hazard plot [11] was created to compare the cumulative incidence of SARSCoV-2 infection among previously infected subjects who were vaccinated, with those of previously infected subjects who remained unvaccinated, previously uninfected subjects who were vaccinated, and previously uninfected subjects who remained unvaccinated. Previous infection was treated as a timeindependent covariate (SARS-CoV-2 infection at least 42 days before Dec 16, 2020), and vaccination (14 days after receipt of the second dose of the vaccine) was treated as a time-dependent covariate (Figure 1). Curves for the unvaccinated were based on data for those who did not receive the vaccine over the duration of the study, and for those who did until the date they were considered vaccinated, from which point onwards their data were recorded into the corresponding vaccinated set. A Cox proportional hazards regression model was fitted with time to SARS-CoV-2 infection as the outcome variable against vaccination (as a time-dependent covariate whose value changed on the date a subject was considered vaccinated)[12]. Previous infection (as a time-independent covariate) and an interaction term for previous infection and vaccination were included as covariates. The phase of the epidemic was adjusted for by including the slope of the epidemic curve as a time-dependent covariate whose value changed continuously with the slope of the epidemic curve. The analysis was performed by NKS and ASN using the survival package and R version 4.0.5 [12-14]. 
medRxiv preprint doi: https://doi.org/10.1101/2021.06.01.21258176; this version posted June 19, 2021. The copyright holder for this preprint (which was not certified by peer review) is the author/funder, who has granted medRxiv a license to display the preprint in perpetuity.

It is made available under a CC-BY-NC-ND 4.0 International license .

\section{RESULTS}

Of 52238 employees included in the study, 2579 (5\%) were previously infected with SARS-CoV-

2.

\section{Baseline characteristics}

Those previously infected with SARS-CoV-2 were significantly younger (mean \pm SD age; $39 \pm$ 13 vs. $42 \pm 13, \mathrm{p}<0.001)$, and included a significantly higher proportion with patient-facing jobs (65\% vs. $51 \%, \mathrm{p}<0.001)$. Table 1 shows the characteristics of subjects grouped by whether or not they were previously infected. A significantly lower proportion of those previously infected (47\%, 1220 subjects) were vaccinated by the end of the study compared to $58 \%$ (28855) of those not previously infected $(\mathrm{p}<0.001)$. Of those vaccinated, 63\% received the Moderna vaccine. Twelve percent of subjects with previous SARS-CoV-2 infection did not have a symptom onset date, suggesting they may possibly have been identified on pre-operative or pre-procedural screening, and may not have had symptomatic infection. When vaccination was begun, the epidemic in Ohio was at the peak of its third wave (Figure 2).

\section{Cumulative incidence of COVID-19}

Figure 3 is a Simon-Makuch plot showing that SARS-CoV-2 infections occurred almost exclusively in subjects who were not previously infected with SARS-CoV-2 and who remained unvaccinated. The cumulative incidence of SARS-CoV-2 infection among previously infected unvaccinated subjects did not differ from that of previously infected subjects who were vaccinated, and that of previously uninfected subjects who were vaccinated. For all three of these groups, the cumulative incidence of SARS-CoV-2 infection was much lower than that of subjects who were not previously infected and who remained unvaccinated. Of the 2154 SARS-CoV-2 infections during the study period, $2139(99.3 \%)$ occurred among those not previously infected who remained unvaccinated or were waiting 
medRxiv preprint doi: https://doi.org/10.1101/2021.06.01.21258176; this version posted June 19, 2021. The copyright holder for this preprint (which was not certified by peer review) is the author/funder, who has granted medRxiv a license to display the preprint in perpetuity.

It is made available under a CC-BY-NC-ND 4.0 International license .

to get vaccinated, and15 $(0.7 \%)$ occurred among those not previously infected who were vaccinated. Not one of the 2579 previously infected subjects had a SARS-CoV-2 infection, including 1359 who remained unvaccinated throughout the duration of the study.

\section{Association of vaccination with occurrence of COVID-19}

In a Cox proportional hazards regression model, after adjusting for the phase of the epidemic, vaccination was associated with a significantly lower risk of SARS-CoV-2 infection among those not previously infected (HR 0.031, 95\% CI $0.015-0.061)$ but not among those previously infected (HR $0.313,95 \%$ CI 0 - Infinity). The absence of events among those who were previously infected, whether they received the vaccine or not, precluded accurate or precise estimates for the latter effect size.

\section{Duration of protection}

This study was not specifically designed to determine the duration of protection afforded by natural infection, but for the previously infected subjects the median duration since prior infection was 143 days (IQR 76 - 179 days), and no one had SARS-CoV-2 infection over the following five months, suggesting that SARS-CoV-2 infection may provide protection against reinfection for 10 months or longer. 
medRxiv preprint doi: https://doi.org/10.1101/2021.06.01.21258176; this version posted June 19, 2021. The copyright holder for this preprint (which was not certified by peer review) is the author/funder, who has granted medRxiv a license to display the preprint in perpetuity.

It is made available under a CC-BY-NC-ND 4.0 International license .

\section{DISCUSSION}

This study shows that subjects previously infected with SARS-CoV-2 are unlikely to get COVID19 reinfection whether or not they receive the vaccine. This finding calls into question the necessity to vaccinate those who have already had SARS-CoV-2 infection.

It is reasonable to expect that immunity acquired by natural infection provides effective protection against future infection with SARS-CoV-2. Observational studies have indeed found very low rates of reinfection over the following months among survivors of COVID-19 [6-8]. Reports of true reinfections are extremely rare in the absence of emergence of new variants. When such reinfections occur, it would be purely speculative to suggest that a vaccine might have prevented them. Duration of protective immunity from natural infection is not known. However, the same also can be said about duration of protective immunity from vaccination. Uncertainty about the duration of protective immunity afforded by natural infection is not by itself a valid argument for vaccinating previously infected individuals. This study provides direct evidence that vaccination with the best available vaccines does not provide additional protection in previously infected individuals.

A prior study concluded that natural infection cannot be relied on to protect against COVID-19 [9]. That study was based on comparison of PCR-positivity rates during a second COVID-19 surge in Denmark between those who tested positive and negative during the first COVID-19 surge, and indirectly calculated that prior infection provided $80.5 \%$ protection against repeat infection, and that protection against those older than 65 years was only $47.1 \%$. The study did not compare vaccinated and unvaccinated people, and it is therefore an assumption to consider that a vaccine would have provided better protection in that particular population. Furthermore, there was a gap of only seven weeks between the end of the first surge and the beginning of the second in that study. It is now well-known that a small number of people can continue to have positive PCR test results for several weeks to a few months after infection, one study finding that $5.3 \%$ remained positive at 90 days [15]. It is possible that some of the positives picked up in the early part of the second surge were not necessarily new infections but residual 
medRxiv preprint doi: https://doi.org/10.1101/2021.06.01.21258176; this version posted June 19, 2021. The copyright holder for this preprint (which was not certified by peer review) is the author/funder, who has granted medRxiv a license to display the preprint in perpetuity.

It is made available under a CC-BY-NC-ND 4.0 International license .

virus from the tail end of the first surge. Since the actual number of infections was small, a few such misclassifications could change the rates substantially. Our study examined rates of SARS-CoV-2 infection in vaccinated and unvaccinated individuals and showed that those previously infected who did not receive the vaccine did not have higher rates of SARS-CoV-2 infection than those previously infected who did, thereby providing direct evidence that vaccination does not add protection to those who were previously infected.

There are several strengths to our study. Its large sample size and follow-up of up to 5 months provide us with an ample degree of confidence in its findings. A major strength of our study is that we adjusted the analyses for the phase of the epidemic at all time points. The risk of acquisition of infection is strongly influenced by the phase of the epidemic at any given time, and it is important to adjust for this for accurate risk analyses. Given that was this a study among employees of a health system, and that the health system had policies and procedures in recognition of the critical importance of keeping track of the pandemic among its employees, we had an accurate accounting of who had COVID-19, when they were diagnosed with COVID-19, who received a COVID-19 vaccine, and when they received it.

The study has its limitations. Because we did not have a policy of asymptomatic employee screening, previously infected subjects who remained asymptomatic might have been misclassified as previously uninfected. Given this limitation, one should be cautious about drawing conclusions about the protective effect of prior asymptomatic SARS-CoV-2 infection. It should be noted though, that $12 \%$ of the subjects classified as previously infected did not have a symptom onset date recorded, suggesting that at least some of those classified as previously infected might have been asymptomatic infections. It is reassuring that none of these possibly asymptomatically infected individuals developed COVID-19 during the duration of the study. The study follow-up duration was short, being only five months, but this was longer than published mRNA vaccine efficacy studies [1,2], and longer than the follow-up duration of the largest published vaccine effectiveness studies to date [3,4]. Median freedom from reinfection (time from initial infection until end of follow-up) in this study, for those previously infected, of almost 10 months, is consistent with findings in an earlier study that immunoglobulin $\mathrm{G}(\mathrm{IgG})$ to the spike protein remained 
medRxiv preprint doi: https://doi.org/10.1101/2021.06.01.21258176; this version posted June 19, 2021. The copyright holder for this preprint (which was not certified by peer review) is the author/funder, who has granted medRxiv a license to display the preprint in perpetuity.

It is made available under a CC-BY-NC-ND 4.0 International license .

stable over more than six months after an episode of infection [16]. Our study included no children and few elderly subjects, and the majority would not have been immunosuppressed. Data governance policies in our institution precluded us from obtaining detailed clinical information on employees. While one cannot generalize this study's findings to assume that prior infection would provide adequate immunity in these groups, there is also no reason to expect a vaccine to provide additional protection in these same groups. Lastly, it is necessary to emphasize that these findings are based on the prevailing assortment of virus variants in the community during the study. It is not known how well these results will hold if or when some of the newer variants of concern become prominent. However, if prior infection does not afford protection against some of the newer variants of concern, there is little reason to suppose that the currently available vaccines would either. Vaccine breakthrough infections with variants have indeed been reported [17].

Our study's findings have important implications. Worldwide, COVID-19 vaccines are still in short supply. As of March 9, 2021, dozens of countries had not been able to administer a single dose of the vaccine [18]. As of May 17, 2021, only 17 countries had been able to reach ten percent or more of their populations with at least the first dose of vaccine [19]. Given such a scarcity of the vaccine, and the knowledge that vaccine does not provide additional protection to those previously infected, it would make most sense to limit vaccine administration to those who have not previously had the infection. In addition to profession, age, and comorbid conditions, previous infection should be an important consideration in deciding whom to prioritize to receive the vaccine. A practical and useful message would be to consider symptomatic COVID-19 to be as good as having received a vaccine, and that people who have had COVID-19 confirmed by a reliable laboratory test do not need the vaccine.

In conclusion, individuals who have laboratory-confirmed symptomatic SARS-CoV-2 infection are unlikely to benefit from COVID-19 vaccination, and vaccines can be safely prioritized to those who have not been infected before. 


\section{TRANSPARENCY DECLARATION}

\section{Conflict of Interest}

Selection of "no competing interests" reflects that all authors have completed the ICMJE uniform disclosure form at www.icmje.org/coi disclosure.pdf and declare: no support from any organization for the submitted work; no financial relationships with any organizations that might have an interest in the submitted work in the previous three years; no other relationships or activities that could appear to have influenced the submitted work.

\section{Funding}

None received.

\section{Author contributions}

NKS: Conceptualization, Methodology, Validation, Investigation, Data curation, Software, Formal analysis, Visualization, Writing- Original draft preparation, Writing- Reviewing and Editing, Supervision, Project administration.

ASN: Methodology, Formal analysis, Visualization, Validation, Writing- Reviewing and Editing.

PCB: Resources, Investigation, Validation, Writing- Reviewing and Editing.

PT: Resources, Writing- Reviewing and Editing.

SMG: Project administration, Resources, Writing- Reviewing and Editing. 
medRxiv preprint doi: https://doi.org/10.1101/2021.06.01.21258176; this version posted June 19, 2021. The copyright holder for this preprint (which was not certified by peer review) is the author/funder, who has granted medRxiv a license to display the preprint in perpetuity.

It is made available under a CC-BY-NC-ND 4.0 International license .

\section{REFERENCES}

1. Polack FP, Thomas SJ, Kitchin N, et al. Safety and Efficacy of the BNT162b2 mRNA Covid-19 Vaccine. N Engl J Med 2020;383:2603-15.

2. Baden LR, El Sahly HM, Essink B, et al. Efficacy and Safety of the mRNA-1273 SARS-CoV-2 Vaccine. N Engl J Med 2021;384:403-16.

3. Dagan N, Barda N, Kepten E, et al. BNT162b2 mRNA Covid-19 Vaccine in a Nationwide Mass Vaccination Setting. N Engl J Med 2021;384:1412-23.

4. Haas EJ, Angulo FJ, McLaughlin JM, et al. Impact and effectiveness of mRNA BNT162b2 vaccine against SARS-CoV-2 infections and COVID-19 cases, hospitalisations, and deaths following a nationwide vaccination campaign in Israel: an observational study using national surveillance data. Lancet 2021;397:1819-29.

5. Beyrer C, Allotey P, Amon JJ, et al. Human rights and fair access to COVID-19 vaccines: the International AIDS Society-Lancet Commission on Health and Human Rights. Lancet 2021;397:1524-7.

6. Sheehan MM, Reddy AJ, Rothberg MB. Reinfection Rates Among Patients Who Previously Tested Positive for Coronavirus Disease 2019: A Retrospective Cohort Study. Clin Infect Dis 2021. Available from: https://doi.org/10.1093/cid/ciab234. Accessed May 5, 2021.

7. Pilz S, Chakeri A, Ioannidis JP, et al. SARS-CoV-2 re-infection risk in Austria. Eur J Clin Invest 2021;51:e13520.

8. Lumley SF, O’Donnell D, Stoesser NE, et al. Antibody Status and Incidence of SARS-CoV-2 Infection in Health Care Workers. N Engl J Med 2021;384:533-40.

9. Hansen CH, Michlmayr D, Gubbels SM, Mølbak K, Ethelberg S. Assessment of protection against reinfection with SARS-CoV-2 among 4 million PCR-tested individuals in Denmark in 2020: a population-level observational study. Lancet 2021;397:1204-12.

10. Centers for Disease Control and Prevention. Frequently Asked Questions about COVID-19 
medRxiv preprint doi: https://doi.org/10.1101/2021.06.01.21258176; this version posted June 19, 2021. The copyright holder for this preprint (which was not certified by peer review) is the author/funder, who has granted medRxiv a license to display the preprint in perpetuity.

It is made available under a CC-BY-NC-ND 4.0 International license .

Vaccination. 2021;Available from: https://www.cdc.gov/coronavirus/2019-

ncov/vaccines/faq.html. Accessed April 26, 2021.

11. Simon R, Makuch RW. A non-parametric graphical representation of the relationship between survival and the occurrence of an event: Application to responder versus non-responder bias. Stat Med 1984;3:35-44.

12. Therneau TM, Crowson C, Atkinson E. Using Time Dependent Covariates and Time Dependent Coefficients in the Cox Model. Available from: https://cran.r-

project.org/web/packages/survival/vignettes/timedep.pdf. Accessed May 8, 2021.

13. Therneau TM, Grambsh, PM. Modeling Survival Data: Extending the Cox Model. New York, NY: Springer International Publishing; 2000.

14. R Core Team. R: A Language and Environment for Statistical Computing. Vienna, Austria: R Foundation for Statisical Computing; 2021.

15. Vibholm LK, Nielsen SSF, Pahus MH, et al. SARS-CoV-2 persistence is associated with antigenspecific CD8 T-cell responses. EBioMedicine 2021;64:103230.

16. Dan JM, Mateus J, Kato Y, et al. Immunological memory to SARS-CoV-2 assessed for up to 8 months after infection. Science 2021;371:eabf4063.https://doi.org/10.1126/science.abf4063.

17. Hacisuleyman E, Hale C, Saito Y, et al. Vaccine Breakthrough Infections with SARS-CoV-2 Variants. N Engl J Med 2021; https://doi.org/10.1056/NEJMoa2105000.

18. The Lancet. Access to COVID-19 vaccines: looking beyond COVAX. Lancet 2021;397:941.

19. Mathieu E, Ritchie H, Ortiz-Ospina E, et al. A global database of COVID-19 vaccinations. Nat Hum Behav 2021;https://doi.org/10.1038/s41562-021-01122-8. 
medRxiv preprint doi: https://doi.org/10.1101/2021.06.01.21258176; this version posted June 19, 2021. The copyright holder for this preprint (which was not certified by peer review) is the author/funder, who has granted medRxiv a license to display the preprint in perpetuity.

It is made available under a CC-BY-NC-ND 4.0 International license .

\section{TABLES}

Table 1. Study Subject Characteristics

\begin{tabular}{|c|c|c|c|}
\hline Characteristic & $\begin{array}{l}\text { Previously Infected } \\
\qquad(\mathrm{N}=\mathbf{2 5 7 9})\end{array}$ & $\begin{array}{l}\text { Not Previously Infected } \\
\qquad(\mathrm{N}=49659)\end{array}$ & $P$ Value \\
\hline Age, $y$, mean \pm SD & $39 \pm 13$ & $42 \pm 13$ & $<0.001$ \\
\hline Patient-facing job & $1676(65)$ & $25504(51)$ & $<0.001$ \\
\hline Job location & & & $<0.001$ \\
\hline Cleveland Clinic Main Campus & $1011(39)$ & $19595(40)$ & \\
\hline Regional hospitals & $1096(43)$ & $16433(33)$ & \\
\hline Ambulatory centers & $313(12)$ & 7767 (16) & \\
\hline Administrative centers & $138(5)$ & $4424(9)$ & \\
\hline Remote location & $21(<1)$ & $1440(3)$ & \\
\hline Job category & & & $<0.001$ \\
\hline Professional staff & $89(4)$ & $3775(8)$ & \\
\hline Residents and fellows & $72(3)$ & $1669(3)$ & \\
\hline Advanced practice practitioners & $154(6)$ & $2806(6)$ & \\
\hline Nursing & $1142(44)$ & $13623(27)$ & \\
\hline Pharmacy & $44(2)$ & $1274(3)$ & \\
\hline Research & $328(13)$ & $6776(14)$ & \\
\hline Clinical support & $111(4)$ & $3500(7)$ & \\
\hline Administration & $614(24)$ & $15050(30)$ & \\
\hline Administration support & $25(1)$ & $1186(2)$ & \\
\hline
\end{tabular}

Data are presented as no. (\%) unless otherwise indicated 
medRxiv preprint doi: https://doi.org/10.1101/2021.06.01.21258176; this version posted June 19, 2021. The copyright holder for this preprint (which was not certified by peer review) is the author/funder, who has granted medRxiv a license to display the preprint in perpetuity.

It is made available under a CC-BY-NC-ND 4.0 International license .

\section{FIGURES}

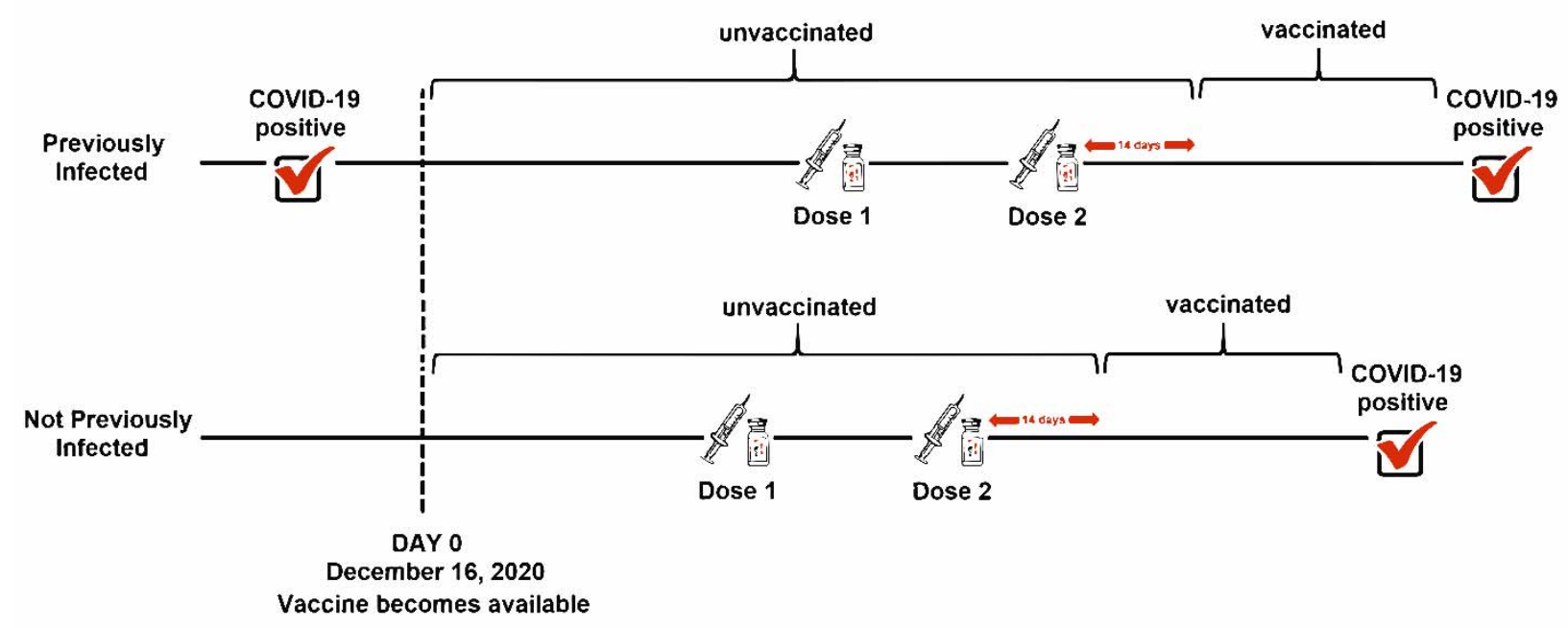

Figure 1. Explanation of "previously infected" analyzed as a time-independent covariate and "vaccinated" treated as a time-dependent covariate. 


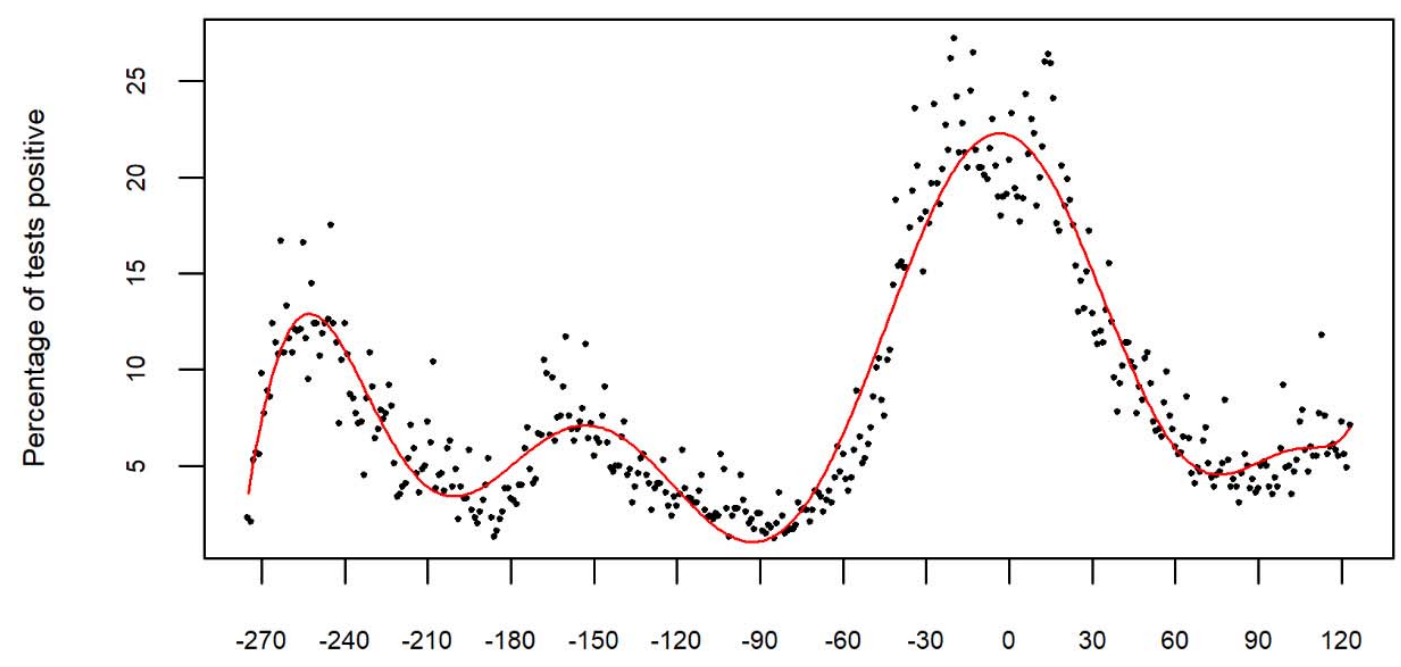

Figure 2. COVID-19 epidemic curve before and after vaccine rollout. Points on the scatter plot represent the proportion of all COVID-19 PCR tests done at Cleveland Clinic that were positive on any given day. The colored line represents a fitted polynomial curve. 


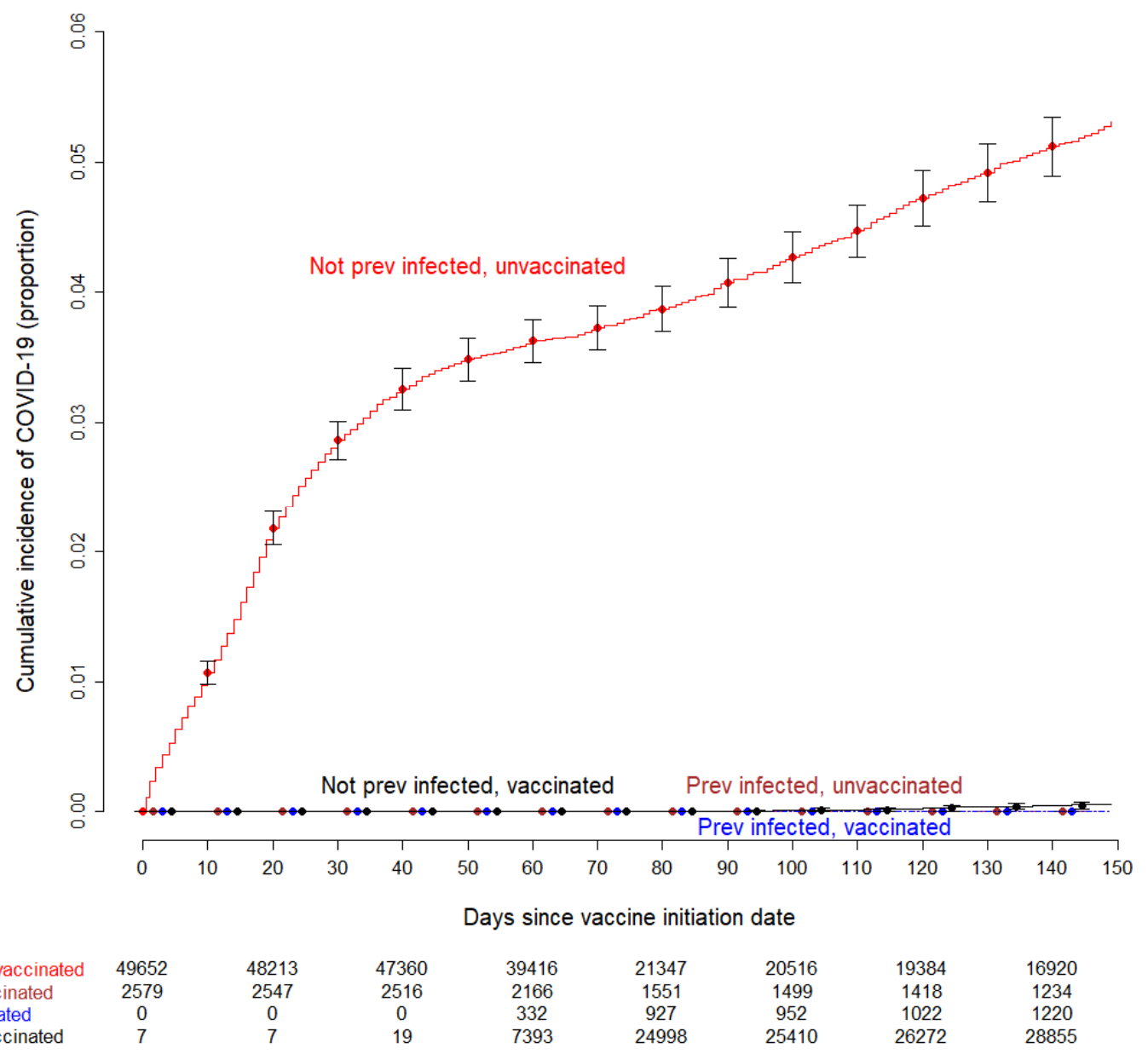

Figure 3. Simon-Makuch plot showing the cumulative incidence of COVID-19 among subjects previously infected and not previously infected with COVID-19, who did and did not receive the vaccine. Curves for the unvaccinated are based on data for those who did not receive the vaccine during the duration of the study, and for those waiting to receive the vaccine. Day zero was Dec 16, 2020, the day vaccination was started in our institution. Error bars represent 95\% confidence intervals. Seven subjects who had been vaccinated earlier as participants in clinical trials were considered vaccinated throughout the duration of the study. Twelve subjects who received their first dose in the first week of the vaccination campaign managed to get their second dose three weeks later, and were thus considered vaccinated earlier than 42 days since the start of the vaccination campaign. 